\title{
Cross-infection in Infantile Gastroenteritis
}

\author{
A. G. IRONSIDE, J. BRENNAND, B. K. MANDAL, and B. HEYWORTH* \\ From the Monsall Hospital, Manchester
}

\begin{abstract}
Ironside, A. G., Brennand, J., Mandal, B. K., and Heyworth, B. (1971). Archives of Disease in Childhood, 46, 815. Cross-infection in infantile gastroenteritis. It is not entirely possible to prevent hospital cross-infection in infantile gastroenteritis by the use of conventional barrier-nursing techniques, even with experienced staff in well-designed wards. An incident of double cross-infection due to enteropathic Esch. coli types $\mathrm{O} 119$ and $\mathrm{O} 126$ and the measures that were taken to control it are described. The type $\mathrm{O} 119$ infections were clinically severe, and the cases showed significant levels of serum antibody to the organism, while the type O126 infections were clinically mild and no antibody was produced. The use of the antibiotic colistin, to which both organisms were originally sensitive, may have been of some value in clearing the type 0119 infection but was without effect on the type $\mathrm{O} 126$ infection, which continued to spread during treatment. A degree of resistance to colistin was found in some strains of the type O126 organism isolated after treatment. The outbreaks largely ended spontaneously, but may have been limited in extent by the administrative measures described. The use of antibiotics in infantile gastroenteritis is reviewed and a plea is made for a modern large-scale trial to reassess their value.
\end{abstract}

The Infectious Diseases Department of Monsall Hospital, Manchester, admits cases of infantile gastroenteritis from the Greater Manchester area. During 1969 the department admitted 656 cases of gastroenteritis under the age of 2 years of which 510 cases were non-specific and 146 cases were due to enteropathic Esch. coli. The cases were admitted to one of two cubicle cot wards where they were barrier-nursed in single cubicles fitted with a baby bath and weighing scales. Maximum use was made of disposable and CSSD equipment. Bottle feeds were supplied by a central milk kitchen divided into 'clean' and 'dirty' rooms which were connected only by a doubleended automatic autoclave. Feeds were terminally pasteurized by steam, then were rapidly cooled and stored in ward refrigerators until used.

In spite of the application of full barrier-nursing techniques by an experienced and dedicated nursing staff, cross-infection is a constant anxiety, and hardly a year passes without incidents occurring, though usually on a small scale. Antibiotics are not used routinely in the management of gastroenteritis

Received 30 April 1971.

^ Present address: MRC Unit, Bathurst, The Gambia, West Africa. unless some complication such as associated respiratory tract infection is present. Recently, trials of colistin (Heyworth, 1970) and Bactrim (to be published) have been carried out in the department in cases of specific Esch. coli gastroenteritis.

\section{Outbreaks}

During September 1970 two cases of Esch. coli type 0119 enteritis were admitted, at a time when both wards were almost filled with a variety of specific and nonspecific types of infectious enteritis. Within two weeks there were 10 cases of cross-infection due to this organism, affecting both wards. All the affected babies had severe diarrhoea, and several had a protracted illness with progressive weight loss and recurrent dehydration, predominantly hyponatraemic in type, requiring longcontinued or repeated intravenous fluid treatment. One baby, already ill and wasted with a severe Esch. coli type $\mathrm{O} 55$ infection, gradually deteriorated and died. Because of the severity of the cross-infection and its occurrence on both wards, all new admissions to the two wards were stopped and the patients were discharged home when they were clinically well and free from infection. On discharge, general practitioners were advised of the outbreak in a special letter and were asked to readmit any relapsing case to the same department. The Medical Officer of Health was advised and the liaison Health Visitor informed all district Health 
Bacteriological and Clinical Ftai

\begin{tabular}{|c|c|c|c|c|}
\hline \multirow{2}{*}{ Case No. } & \multirow{2}{*}{ Age (mth) } & \multicolumn{3}{|c|}{ Before Treatment } \\
\hline & & Original Pathogens & Cross Infection (1) & Cross Infection (2 \\
\hline $\begin{array}{l}1 \\
2 \\
3\end{array}$ & $\begin{array}{l}1 \frac{1}{2} \\
1 \frac{1}{2} \\
2 \frac{1}{2}\end{array}$ & $\begin{array}{l}\text { Esch. coli } 055 \\
\text { Esch. coli O26 } \\
\text { Salmonella typhimurium }\end{array}$ & $\begin{array}{l}\text { Esch. coli } 0119 \\
\text { Esch. coli } \overline{0119}\end{array}$ & $\begin{array}{l}\text { Esch. coli } \overrightarrow{0126} \\
\text { Esch. coli } 0126\end{array}$ \\
\hline $\begin{array}{l}4 \\
5\end{array}$ & $\begin{array}{l}2 \\
2\end{array}$ & Salmonella typhimurium & $\overline{-}$ & Esch. coli 0126 \\
\hline $\begin{array}{l}6 \\
7\end{array}$ & $\begin{array}{l}2 \\
11\end{array}$ & Esch. coli $\overline{086}$ & $\begin{array}{l}\text { Esch. coli } 0119 \\
\text { Esch. coli } 0119\end{array}$ & 二 \\
\hline 8 & 1 & - & - & Esch. coli $\mathrm{O} 126$ \\
\hline $\begin{array}{r}9 \\
10\end{array}$ & $\begin{array}{l}4 \\
21\end{array}$ & 二 & $\begin{array}{l}\text { Esch. coli O119 } \\
\text { Esch, coli O119 }\end{array}$ & Esch, coli $\overrightarrow{0126}$ \\
\hline 11 & 7 & Esch. coli 0114 & Esch. coli 0119 & - \\
\hline 12 & 4 & Esch. coli $\mathrm{O} 26$ & - & Esch. coli 0126 \\
\hline 13 & 2 & Shigella sonne & Esch. coli 0119 & - \\
\hline 14 & 3 & Esch. coli 0119 & - & - \\
\hline 15 & 7 & Esch. coli 055 & $=$ & - \\
\hline 16 & 3 & Esch. coli $\mathrm{O} 26$ & Esch. coli 0119 & Esch. coli 0126 \\
\hline 17 & 7 & - & Esch. coli 0119 & - \\
\hline 18 & 6 & Salmonella typhimurium & - & - \\
\hline
\end{tabular}

*Clinical severity: $+=$ moderate; $++=$ severe; $+++=$ very severe.

Visitors of discharges, so that extra observation could be maintained at home and so that the babies would not be taken prematurely to Infant Welfare Clinics until the risk of relapse was over. After closing the wards to new admissions, there were seven more cases of crossinfection due to Esch. coli type O126, of which there was already a single case in the department. Fortunately this second episode of cross-infection was not clinically severe as several of the babies were crossinfected for the second time. About 10 days after closure to admissions it was possible to accommodate the remaining babies on one ward, after which the other ward was cleaned, disinfected, and then reopened for new admissions only and not for readmissions. It was then decided to treat all the babies on the 'infected' ward with an antibiotic to which both organisms weresensitive. The 18 babies were treated with a 10-day course of colistin, intramuscularly for 3 days in a dose of 50,000 units per $\mathrm{kg}$ per day in 3 divided doses, and then by mouth for 7 days in a dose of 150,000 units per kg per day in 4 divided doses. Apart from the baby who died on the fourth day of treatment, all the babies improved clinically before the beginning of the drug trial and all continued to improve throughout the treatment period, without apparent ill effects.

The Table shows the isolations of faecal pathogens before and after treatment, the clinical severity of the type 0119 infections and the antibody responses found in the type 0119 and the salmonella infections. The bacteriological isolations in the table are broken down as follows.

Original pathogens. These comprised 8 different types of enteropathic organisms which had been present for several weeks and in some cases were clearing bacteriologically before treatment began.

Cross-infection 1. This comprised the type 0119 infections present for 2 to 3 weeks before treatment began; the cases were improving clinically.

Cross-infection 2. This comprised the Esch. coli type O126 infections, only present for a few days and clinically mild or asymptomatic.

Residual pathogens. These comprised the organisms isolated after treatment from daily rectal swabs over a 2-week period to a total of 11 or 12 .

\section{Results}

The results showed that all the original pathogens were eradicated, with the exception of the salmonella infections and a single late cross-infection with Esch. coli type 086. 10 out of the 11 Esch. coli type 0119 infections were also eradicated, but in the case of the Esch. coli type 0126 infections, which had been present for the shortest time, only 3 out of the original 7 cases were cleared and 5 new cases were cross-infected during the treatment.

Antibiotic sensitivities by the disc method showed that all the organisms were sensitive to colistin before and after treatment. However, when this was checked by the tube dilution method some of the strains of Esch. coli type O126 isolated 
cases and untreated controls. In another series (Lamb, 1968) a clearance rate of $90 \%$ was reported in colistin-treated cases, but a number of cases required retreatment and there were no controls, so that the superiority of treatment over the natural clearance rate was not established. A third report (Valman and Wilmers, 1969), suggested that gentamicin eliminated the excretion of pathogenic Esch. coli (in this case type O114), but gave no bacteriological data to confirm this. In the present report, the Esch. coli type $\mathrm{O} 119$ was eliminated in $90 \%$ of cases but the type 0126 in less than $50 \%$ of the cases, so that no consistent result was seen.

A more complex issue is whether antibiotics can control the spread of infection. Valman suggested that antibiotics could control the spread of infection but in the series quoted, all possible cases were infected before treatment began, so that the point was not established. In the present series, the type 0119 infection had already stopped spreading as no new case had occurred for more than a week before treatment began, but in the type 0126 infection, the organism continued to spread without check to new cases during the treatment, so it appears that the blanket use of antibiotics cannot reliably control the spread of these infections.

The most complex issue is whether antibiotics can influence the clinical course of the illness. Opinions based on experience have gradually come round to the view that antibiotics have little to offer (British Medical Journal, 1970) and that their routine use in this condition is a form of environmental pollution. The main published work is the multicentre controlled trials carried out by the Medical Research Council (1953). The conclusions of these trials were that sulphadiazine, and to a lesser extent chloramphenicol, could prevent mild cases from becoming severe and could shorten the course of the illness, while chlortetracycline could do the former but not the latter. Apart from the fact that the two most recommended drugs are no longer used in the disease, the trial itself showed disquieting irregularities. In one centre comparing chlortetracycline treated and control cases, the 50 control cases received sulphadiazine in 27 instances, chlortetracyline or chloram- phenicol in 13 instances, and penicillin or streptomycin in 20 instances. In spite of the fact that the 'controls' received more antibiotics than the treatment group, the results from this centre provided the only significant advantage for chlortetracycline in the entire trial. Apart from these irregularities, some of the data in the trial suggest that the aetiology of the disease has changed in the past 20 years. The incidence of the two types of enteropathic Esch. coli known then averaged 37\% and was as high as $80 \%$ in some centres in the M.R.C. trial. This is quite different from the recently reported incidence of $4 \%$ of these original serotypes (Ironside, Tuxford, and Heyworth, 1970) and overall incidences of the 10 currently recognized pathogenic types of 16-22\% (Ironside et al., 1970) and 12-20\% (Wilmers and Valman, 1969).

As most of the recently published work has been of series of inadequate size or without adequate controls, there appears to be a need for a large modern controlled trial to reassess the value of antibiotics in infantile gastroenteritis.

We would like to thank Sisters Howard, Mills, Gibbons, and Adams, and Drs. Sengupta, Qazi, Atando, and Reddy for their devoted and skilled work in the management of these difficult and worrying cases.

\section{REFERENCES}

British Medical fournal (1970). Leading article. Infantile gastrot enteritis, $3,2$.

Heyworth, B. (1970). Colistin and other antibiotics in the treatment of specific gastro-intestinal infections. Medical Officer, $123,349$.

Ironside, A. G., Tuxford, A. F., and Heyworth, B. (1970). A survey of infantile gastroenteritis. British Medical fournal, 3, 20.

Lamb, R. (1968). Colistin sulphate in the treatment of specific bacterial intestinal infections. Scottish Medical fournal, 13, 9.

Medical Research Council (1953). Antibiotic and chemotherapeutic agents in the treatment of infantile diarrhea and vomiting. Lancet, 2, 1163.

Valman, H. B., and Wilmers, M. J. (1969). Use of antibiotics in acute gastroenteritis among infants in hospital. Lancet, 1, 1122 .

Wilmers, M. J., and Valman, H. B. (1969). Antibiotics in acute gastroenteritis. (Correspondence.) Lancet, 2, 113.

Correspondence to Dr. A. G. Ironside, Department of Infectious Diseases, Monsall Hospital, Manchester M10 8WR. 